\title{
Agronomic-productive Characteristics of Two Genotype of Stevia Rebaudiana in Central Italy
}

\author{
Laura Andolfi, Mario Macchia, Lucia Ceccarini* \\ Dipartimento di Agronomia e Gestione dell'Agroecosistema, Università di Pisa \\ Via San Michele degli Scalzi 2, 56124 Pisa, Italy
}

Received: 9 February 2004. Accepted: 10 March 2006

\begin{abstract}
Stevia rebaudiana Bertoni produces a variety of high-potency low calorie sweeteners in its' leaf tissue. The aim of this work was to evaluate the productive potential of two different Stevia rebaudiana genotypes and the characteristics of the production of the plant obtained through different cultivation methods, in central Italy. For several years (1992-2000) agronomic trials on Stevia rebaudiana cultivated in the littoral area near Pisa (Italy) carried out. In 1992 two different genotypes of Stevia (B1 and B2) transplanted in silt-loam soil; in 1996 other plants from B2 genotype, produced by vegetative process (micropropagation), were transplanted in the same field. In the period from 1992-1999 the production of leaves from both genotypes increase as of the third year and the ratio leaf-aerial plant, after the peak in the third year, tends to diminish. Except the first year (1997) there were not recorded statistically significant differences between the two propagation methods employed in relation to leaf production. The quantity of leaves produced from a single harvest was less than resulting from two cuttings and the micropropagation plants produced a larger amount of leaves than those from cutting. The leaf-stem ratio was to become an interesting morphological and production characteristic parameter of the plant. Stevia rebaudiana appears particularly suited for the cultivation environment of central Italy. A particular positive aspect that must be considered in these regions is that Stevia can be grown successfully as poliannual species because crop survival over the winter is high. The results obtained show that this species is economically profitable until the 5th or 6th year of cultivation. At our latitudes is also necessary to establish a program of genetic improvement in order to develop earlier varieties that can guaranty an optimum qualitative and quantitative seed production.
\end{abstract}

Key-words: genotype, harvest, propagation, Stevia rebaudiana.

\section{Introduction}

Stevia rebaudiana Bertoni is a plant originated in Paraguay and northeast Brazil. The first indications of the existence of this plant go back to its use by the Guaranì an indigenous tribe who called it Caà-êhê (sweet grass) (Lewis, 1992).

Its first botanical description is attributed to M. Bertoni in 1887. The plant was first called Eupatorium rebaudianum Bert. in honor of Rebaudi, the first chemist to study the chemical characteristics of the substances extracted. Later its name was changed to the current one and it was recommended not only food production, but also medicine for the particular medicinal effects that were attributed to it (Bertoni, 1905).
In 1943 the first seeds were exported to the United Kingdom where it was cultivated unsuccessfully. In 1968 it was exported to Japan and from there awareness and cultivation of the plant spread throughout the world, particularly to Southeast Asia (Lewis, 1992).

Recently, Stevia rebaudiana Bertoni has been acquiring consistently increasing economic interest, due to the presence in its leaves of a large number of sweet constituents: diterpene glycosides. These substances are characterized by the presence within their structure of 3 molecules of glucose. Of the four sweeteners found in greatest concentration in the leaves (stevioside, rebaudioside $\mathrm{A}$, rebaudioside $\mathrm{C}$, dulcoside $\mathrm{A}$ ), stevioside and rebaudioside $\mathrm{A}$ have well documented physical and sensory properties (Nardi, 1996). 
Stevioside is present in greater quantities (3$10 \%$ of the dry matter of the leaves) than the other compounds and can be used as a sweetening agent in all foods because it is highly stable at high temperatures and in acid environments. It has characteristics similar to saccharose, but has no calories. In a $93-95 \%$ pure form, it leaves a bitter, astringent aftertaste which is still preferable to that of glycyrrhizin or aspartame (Nardi, 1996). Rebaudioside A (1-3\% of the dry matter) is sweeter than stevioside and is considered to have a less astringent, less bitter taste and a less persistent aftertaste, and is, therefore, judged to be the one with the most pleasant sensory characteristics. The other two compounds, rebaudioside $\mathrm{C}$ and dulcoside $\mathrm{A}$, occur in very low concentrations in the leaves (approximately 0.6 and $0.3 \%$ respectively) (Brandle et al., 1992).

Today, there are many extraction, purification and transformation industries in Japan where this product is used as a sweetener in both solid food and in beverages to substitute conventional sugars and in dietetic products. From there, cultivation has spread to China, India, Korea, Indonesia (Handro and Ferreira, 1989). A large part of the product harvested in these countries is exported to Japan where, in 1991, a production of $1550-2000 \mathrm{t}$ dry matter of Stevia rebaudiana Bertoni extracts was reached (Nardi, 1996).

The production of stevia in Brazil and Paraguay covers the internal demand of each of these countries with a large portion exported to the United States and Canada as well.

In Europe, the species is grown for scientific purposes in Belgium, Spain and the United Kingdom (Scientific Committee on Food, 1999). In Italy the stevia is a plurennial (Ruta et al., 1999), while in Canada, for example, it is generally grown as an annual (Brandle and Rosa, 1992).

The stevia is usually transplanted in open fields (Carneiro, 1990; Brandle et al., 1992); in Italy, the ideal period is the month of April, because of the usually mild temperatures and frequent rain (Ruta et al., 1999). Planting density is a fundamentally important parameter of cultivation method, because it directly affects the degree of primary and secondary branching, the height of the plants, the diameter of the stem, the leaf area index, the number of blossomings, and, therefore, the production (Katayama et al.,
1976; Carneiro, 1990; Ruta et al., 1999). With respect to nutritional requirements during the period of maximum growth the cultivation requires a great quantity of nutritional elements such as K, N and Ca (De Lima Filho et al., 1997 a, b; Utumi et al., 1999). Harvest can be performed in a single cutting before blooming or more cuttings per year can be planned (Carneiro, 1990).

Cultivation studies carried out in Italy have given a fresh leaf production of $13.3 \mathrm{t} \mathrm{ha}^{-1}$ in the first year, but in the third year production was in sharp decline (9 t ha-1, Ruta et al., 1999). The biomass that is harvested must be desiccated and then the leaves can be separated from the stems (Brandle et al., 1992).

Various methods can be adopted to extract the sweetening substances from the leaves (Hashimoto et al., 1978; Kasai et al., 1987; Ahmed and Dobberstein, 1982; Kinghorn et al., 1982; Kinghorn et al., 1984; Little and Stahel, 1984; Kitada et al., 1989; Fullas and Chiang, 1989; Fuh and Chiang, 1990; Liu et al., 1997).

The objective of the present work was to evaluate the yield potential of two different Stevia rebaudiana genotypes and the characteristics of the production of the plant obtained through two different vegetative processes (propagation from cutting and micropropagation). In the last two year period of this study we were evaluated the quantity of leaves obtained by different harvest methods: single cutting or two cuttings.

\section{Materials and methods}

For several years, the Department of Agronomy and Agroecosystem Management at the Rottaia Agricultural Center in San Piero a Grado (Pisa, Italy) has been conducting agronomic trials on stevia. Experimentation involves two different genotypes of Stevia rebaudiana Bert. (B1 and B2) started from seed from Brazil.

The plants were transplanted in May, 1992 at a density of 4.5 plant $\mathrm{m}^{-2}$ in a silt-loam soil (sand $15.5 \%$; silt $65.5 \%$; clay $18.0 \%$; organic matter $1.15 \%$; $\mathrm{pH} 8.1$ ) with a rather shallow water table never deeper than $120 \mathrm{~cm}$ below the surface of the ground. The basic fertilization consisted of $100 \mathrm{~kg} \mathrm{ha}^{-1}$ each of nitrogen, phosphorous and potassium and was repeated every year at the 
end of winter. The quantity of nitrogen distributed was always divided into two equal parts, one of which was used for winter fertilization and the other was applied immediately after resumption of growth by the plants (April). The seedlings were irrigated several times after transplanting to help them to take root. During the growth cycle, the plants were watered again only in periods of major water shortage. In 1996, other plants from the B2 genotype (resulted higher yield than B1 genotype) were produced by vegetative process (by propagation from cuttings and micropropagation). At the end of $\mathrm{Au}-$ gust of the same year, approximately 300 internodal cuttings were taken from the 5-year old parent plants in the open field. These cuttings were then treated with indolacetic acid (I.A.A.) and planted in a cold nursery where they spent the winter. At the same time, shoots were taken from plants of the same genotype (B2) from which new vegetative apices were obtained through micropropagation. Other seedlings were obtained from these rootings. In the spring of the following year, both the rooted cuttings and the plants obtained through micropropagation were transplanted in a neighboring field using the same cultivation methods previously described.

With respect to production, it was interesting to examine the dry matter produced from the leaves and the leaf-stem ratio in the long period from 1992 to 1999, and the characteristics of the production of the plants obtained through the different propagation methods. From 1992 to 2000, during the pre-blossom phase (autumn), analyses were performed on a previously designated trial area to establish the attainable production per unit of surface area. In the last two year period, an additional analysis was performed in the vegetative phase to evaluate production potential of the species when subjected to two cuttings (in June and in October) and compare it to that obtainable in the same year with only one cutting.

Data were analyzed using an analysis of variance (Anova). In the period 1997-2000 the two methods of propagation (cutting and micropropagation) were arranged in a completely randomize design replicated four times. In the period 1999-2000 we use a factorial combinations of the treatments, with four replications, analyzing interaction between propagation and harvest methods. For each year means were sep- arated on the basis of least significant differences (LSD) only when the F-test of the Anova for treatments was significant at the 0.05 or 0.01 probability level.

\section{Results and discussion}

The results of experimentation illustrated in Figure 1 show an increase in the production of leaves from both genotypes as of the third year. In the B1 genotype this production already falls drastically by the 6th year. The quantity of dry matter produced from the leaves decreases from $136 \mathrm{~g} \mathrm{plant}^{-1}$ obtained in 1996 to $91 \mathrm{~g} \mathrm{plant}^{-1}$ measured the following year. Instead, in the B2 genotype, in the 6th year as well, we measured a utilizable production, expressed as dry matter, similar to that of the preceding year, and specifically, $146 \mathrm{~g}_{\text {plant }}{ }^{-1}$. The drop in yield can be seen to occur in the 7 th year when the leaf production registered was approximately $103 \mathrm{~g} \mathrm{plant}^{-1}$.

It is interesting to note that in the two genotypes, the trend of the leaf-total plant ratio (Figure 2) is generally the same, indicating that in

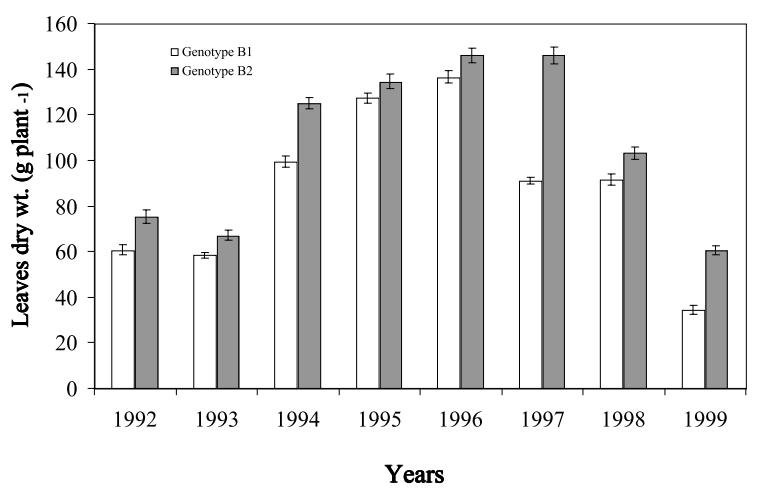

Figure 1. Stevia rebaudiana Bert: production of leaves from both genotypes (B1 and B2) in 1992-1999 years.

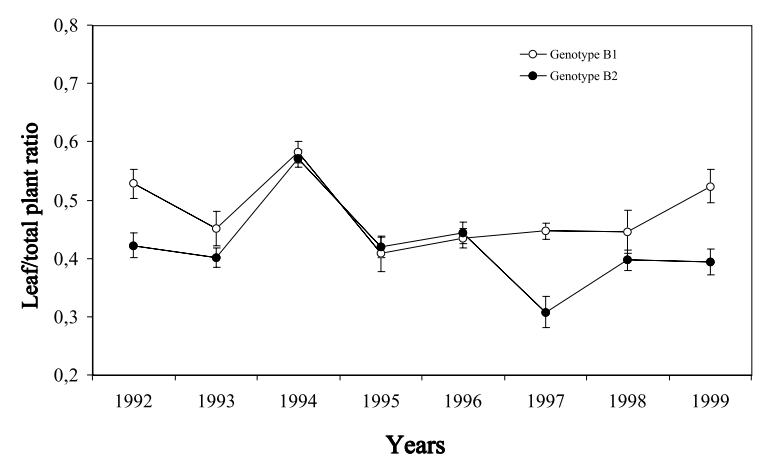

Figure 2. The leaf/total plant ratio of both genotypes in the period of experimentation. 
the third year we observed an increase in the production of leaves proportional to leaf-total plant ratio. After the third year, repeating the number of cuttings as time goes on, the plant tends to produce an increasing number of new stems, and the leaf-total plant ratio thus tends to diminish.

The production of dry leaves produced from the plants of the B2 genotype propagated agamically, in the period 1997-2000, was been examinated (Figure 3). We can see that only in the first year of the planting we recorded statistically significant differences for the different propagation methods. In fact, the plants obtained from cuttings were more developed at the time of transplanting in the open field compared to those that were micropropagated, and this difference was still evident when the first cutting was taken.

By the second year, the leaf production of the plants propagated from cuttings had already reached $113 \mathrm{~g}$ of dry matter per plant and maintained relatively high values in the third year as well, whereas in the fourth year there was a decrease in utilizable product to a value of $60 \mathrm{~g}$ plant $^{-1}$. The plants obtained through micropropagation reached a maximum leaf production one year later than those from cuttings, and even in the fourth year maintained a fairly good production capacity, yielding approximately 98 $\mathrm{g}$ plant $^{-1}$ of utilizable product. Averaging the quantity of leaves produced from the plants obtained through agamic reproduction, we can observe that the production after the first year (57 g plant ${ }^{-1}$ ) increased by $80.7 \%$, while in the fourth year the utilizable yield dropped by $30 \%$ to a value of $79 \mathrm{~g}^{\text {plant }^{-1}}$. The greatest produc-

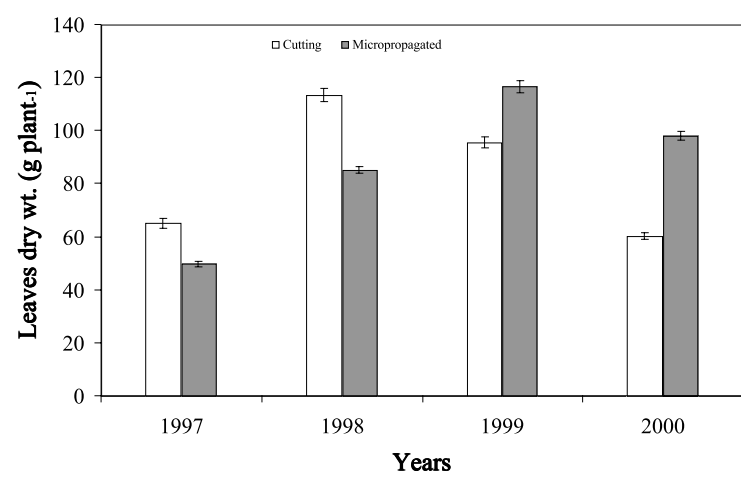

Figure 3. Quantity of dry leaves produced from the plants of the B2 genotype propagated agamically.
Table 1. Dry leaves g plant $\mathrm{t}^{-1}$ yield. Propagation $\mathrm{x}$ harvest methods interaction for the B2 genotype in 1999-2000.

\begin{tabular}{clcc}
\hline Year & & Cutting & Micropropagated \\
\hline 1999 & Single cutting & $54.0 \mathrm{~b}$ & $155.0 \mathrm{a}$ \\
& Two cuttings & $89.5 \mathrm{~b}$ & $94.1 \mathrm{~b}$ \\
2000 & Single cutting & 50.0 & 94.0 \\
& Two cuttings & 64.1 & 103.0 \\
\hline
\end{tabular}

For each year means followed by the same letters are not significantly different at the 0.05 probability level according to LSD test.

tion, obtained in 1999 can be attributed in part to the climatic trend during that summer when there was a high rainfall.

In the period between 1999 and 2000, two different harvest methods were compared for the B2 genotype (Table 1). From analyses of the variation relative to 1999 , a significant observation arises due to the effect of the interaction between the two propagation methods and the two harvest methods. When a single cutting is performed, the micropropagated material produced a quantity of utilizable dry matter statistically greater than that of the other theses. This appears to be associated with the lesser capacity to develop vegetation that yields adequate production after the first cutting. Though not giving rise to noteworthy differences, when the plants reproduce from cuttings, the quantity of leaves produced with two cuttings is greater than that harvested from a single cutting (Table 1). Instead, in the following year, performing two cuttings, utilizable production increased for both propagation methods. The quantity of leaves produced from a single harvest was less than that resulting from two cuttings; the micropropagated plants, in both of the harvest methods, produced a larger amount of leaves than those from cuttings (Table 1). Statistically significant differences emerged concerning the average production obtained from the two methods of harvest employed: $83.6 \mathrm{~g} \mathrm{plant}^{-1}$ is the significant greater two cuttings mean and 72 $\mathrm{g}$ plant $^{-1}$ is the single cutting mean.

The leaf/total plant ratio was to become an interesting morphological and production characteristic parameter of the plants. In Figure 4, we can see that in the first years that ratio tended to increase gradually, especially in the micropropagated plants, where it goes from a minimum in the year of planting to a maximum in 2000. Unlike these, in the plants produced from 


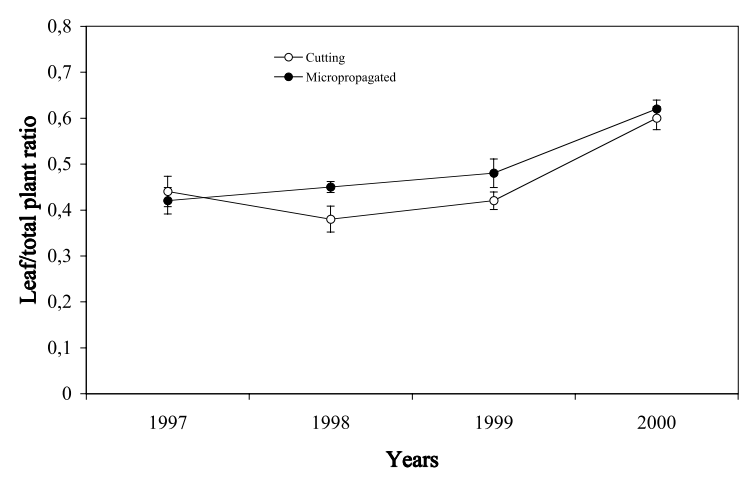

Figure 4. The leaf/total plant ratio of the B2 genotype.

cuttings, the minimum value was reached in the second year, whereas in the last year they had a maximum value. As time goes on, therefore, tillering in the species tends to increase producing increasingly slender stems.

The average values of the leaf/total plant ratio in the case where two different harvest methods were employed in the plants reproduced agamically are seen in Table 2 . As previously seen, for the plants that were cut once, there is an evident increase in these values as they age (0.4 and 0.7). When two cuttings are performed, the high values obtained in both years (1999 and 2000) resulted from the first cutting ( 0.6 and 0.7 respectively). When compared to the case of a single cutting, the higher values obtained from the spring cutting could be due to the fact that in the course of the cultivation cycle, stevia tends to loose the older leaves closest to the ground, and so, if a first cutting takes place when the plants are still in full vegetative development, this process is reduced or eliminated. The values of the leaf/total plant ratio arising from the second cutting (0.6 for both the years), though high, are lower

Table 2. The ratio leaf/total plants for different harvest methods for the B2 genotype

\begin{tabular}{lccc}
\hline & & \multicolumn{2}{c}{ Year } \\
& 1999 & \multicolumn{2}{c}{2000} \\
\cline { 2 - 4 } & & Cutting & Micropropagated \\
\hline First cutting & $0.6 \mathrm{a}$ & $0.7 \mathrm{a}$ & $0.6 \mathrm{~b}$ \\
Second cuttings & $0.6 \mathrm{a}$ & $0.6 \mathrm{~b}$ & $0.6 \mathrm{~b}$ \\
Single cutting & $0.4 \mathrm{~b}$ & $0.6 \mathrm{~b}$ & $0.7 \mathrm{a}$ \\
\hline
\end{tabular}

For each year means followed by the same letters are not significantly different at the 0.05 probability level according to LSD test. than those obtained in June. This result thus demonstrates a tendency of the cultivation to produce a biomass, composed in large part of stems, after the cutting that takes place during the vegetative phase. This is also confirmed by the values reported in Table 1, referring to the leaf production in plants subjected to the two harvest methods.

\section{Conclusions}

The species adapted quite well to the agronomic and climatic environment of this study showing good yield levels of utilizable product. Stevia responds well to vegetative reproduction resolving, at least in part, the problem of seed production that occurs at our latitude. However, both micropropagation and production from cuttings have a great effect on planting costs of this cultivation, even though these costs can be amortized over the years because this species is a plurennial in our cultivation area.

The results of our study show that outdoor cultivation is economically profitable until the 5 th or 6th year. Also, by adopting a suitable method of cultivation, which calls for complete supplementation of the water requirement during the summer season, more than one harvest per year can be achieved. Given the great morphological and productive differences, it is necessary to carry out further research to select individual plants among those in our possession that would be desirable for their phenology, morphology and production potential in order to have at our disposal varieties of Stevia rebaudiana that are richer in rebaudioside A. This has the same potential as a sweetener as stevioside, but a much less perceptible liquorice aftertaste.

Finally, for the photoperiod requirements typical of this species, it is necessary to establish a program of genetic improvement in order to develop earlier varieties that can guaranty an optimum qualitative and quantitative seed production in our latitudes.

\section{Acknowledgements}

The authors are grateful to the "Specchiasol srl" Bussolengo (VR, Italy) for the financial support. 


\section{References}

AA.VV. 1999. Opinion on Stevia rebaudiana Bertoni plants and leaves. Scientific committee on food 17/6/99. European Commission.

AA.VV. 1999. Opinion on stevioside as a sweetener. Scientific committee on food 17/6/99. European Commission.

Ahmed M.S., Dobberstein R.H. 1982. High performance liquid chromatographic separation and quantitation of rebaudisides B, D and E, dulcoside A, and steviolbioside. J. of Chromatography, 245:373-376.

Bertoni M. 1905. Le Kaà He-é Sa nature et ses proprietes. Anales Cientificos Paraguayos, 5:1-14.

Brandle J.E., Rosa N. 1992. Heritability for yield, leaf: stem ratio and stevioside content estimated from a landrace cultivar of Stevia rebaudiana. Can. J. Plant Sci., 72:1263-1266.

Brandle J.E., Starrat A.N., Gijzen M. 1992. Stevia rebaudiana: Its biological, chemical and agricultural properties. Southern crop protection and food reseach centre Agriculture and agrifood Canada.

Bridel M.M., Lavielle R. 1931. Le principe à saveur sucree du Kaà-he-è (Stevia rebaudiana).

Carniero J.W. 1990. Stevia rebaudiana (Bert.) Bertoni. M.Sc. Thesis, State University of Maringa, Brazil.

De Lima Filho O.F., Malavolta E., De Sena J.O.A., Carneiro J.W.P. 1997a. Absorçào e accumulaçào de nutientes em estevia Stevia rebaudiana (Bert.) Bertoni: Macronutrientes. Sci. Agric., 54:14-22.

De Lima Filho O.F., Malavolta E. 1997b. Sintomas de desordens nutricionais em estevia Stevia rebaudiana (Bert.) Bertoni. Sci. argic., 54:53-61.

Fuh W., Chiang B. 1990. Purification of Steviosides by membrane and ion exchange processes. J. Food Sci., 55:1454-1457.

Fullas F., Kim J., Compadre C.M., Kinghorn A.D. 1989. Separation of natural product sweetening agents using overpressured layer chromatography. J. of Chromatography, 464:213-219.

Handro W., Ferreira C.M. 1989. Stevia rebaudiana (Bert.) Bertoni: Production of natural Sweeteners. Biothechnology in Agriculture and Forestry, 7:468-487.

Hashimoto Y., Moriyasu M., Nakamura S., Ishiguro S., Komuro M. 1978. High-performance liquid chromatographic determination of Stevia components on a hydrophilic packed column. J. of Chromatography, 161:403-405.

Kasai R.Y., Yamaguchi H., Tanaka O. 1987. Higth-performance liquid chromatography of glycosides on a new type of hydroxypatite column. J. of Chromatography, 407: 205-210.

Katayama O., Sumida T., Hayashi H., Mitshuashi H. 1976. The pratical application of Stevia and research and development data (English traslation). I.S.U. Company, Japan. pp.747.

Kinghorn A.D., Nanayakkara N.P.D., Soejarto D.D., Medon P.J., Kamath S. 1982. Purification of Stevia re- baudiana sweet constituents by droplet counter-current chromatography. J. of Chromatography, 237:478483.

Kinghorn A.D., Soejato D.D., Nanayakkara N.P.D., Compadre C.M., Makapugay H.C., Hovanec-Brown J.M., Medon P.J., Kamath S.K 1984. A phytochemical screening procedure for sweet ent-kaurene glycosides in the genus Stevia. J. of Nat. Products, 47:439-444.

Kitada Y., Sasaki M., Yamazoe Y., Nakazawa H. 1989. Simultaneus determination of stevioside, rebaudioside $\mathrm{A}$ and $\mathrm{C}$ and dulcoside $\mathrm{A}$ in foods by high-performance liquid chromatography. J. of Chromatography, 474:447-451.

Lewis W. 1992. Early uses of Stevia rebaudiana (Asteraceae) leaves as a sweetener in Paraguay. Economic Botany, 46:336-337.

Little C.J., Stahel O. 1984. Role of column switching in semi-preparative liquid chromaography. Isolation of the sweetener stevioside. J. of Chromatography, 316: 105-111.

Liu J., Ong C.P., Li S.F.Y. 1997. Subcritical fluid extrction of Stevia sweeteners from Stevia rebaudiana. J. Chromat. Scien., 35:446-450.

Lovering N. M. 1996. First report of Septoria steviae on Stevia (Stevia rebaudiana) in North America. Plant dis. 80, pp. 959.

Matsui M., Matsui K., Kawasaki Y., Oda Y. Noguchi T., Kitagawa Y., Sawada M., Hayashi M., Nohmi T., Yoshihira K., Ishidate M., Sofuni T. 1996. Evaluation of the genotoxicity of stevioside and steviol using six in vitro and one in vivo mutagenicity assay. Mutagenesis, 11:573-579.

Metivier J., Viana A.M. 1979. The effect of long and short day length upon the growth of whole plants and the level of soluble proteins, sugars, and stevioside in leaves of Stevia rebaudiana Bert. J. Exper. Botany, 30:1211-1222.

Nardi U. 1996. Stevia rebaudiana: analisi su un dolcificante naturale. Erboristeria domani, 6:58-64.

Pezzuto J.M., Compadre C.M., Swanson S.M., Nanayakkara N.P.D., Kinghorn A.D. 1985. Metabolically activated steviol, the aglycone of stevioside, is mutagenic. Proc. Natl. Acad. Sci. USA 82:2478-2482.

Planas G.M., Kuc J. 1968. Contraceptive properties of Stevia rebaudiana. Science, 162:1007.

Redaelli C. 1983 Droghe ad attività ipoglicemizzante: Stevia rebaudiana. B. Bonomelli S.p.a. Dolzago (Como).

Reeleder R. 1999. Septoria leaf spot of Stevia rebaudia$n a$ in Canada and methods for screening for resistence. J. Phytopathology, 147:605-613.

Ruta C., De Mastro G., Fortunato I.M., Mazzi V. 1999. Modalità di propagazione e tecniche di coltivazione di Stevia rebaudiana Bertoni. 33 ${ }^{\text {th }}$ Congress SIA Agripolis, Padova (Italy).

Utumi M.M., Monnerat P.H., Pereira P.R.G., Fontes P.C.R., Godinho V. 1999. Macronutrient deficiencies in Stevia: visual and effects on growth, chemical composition, and stevioside production. Pesquisia Agropecuaria Brasileira, 34:1039-1043. 